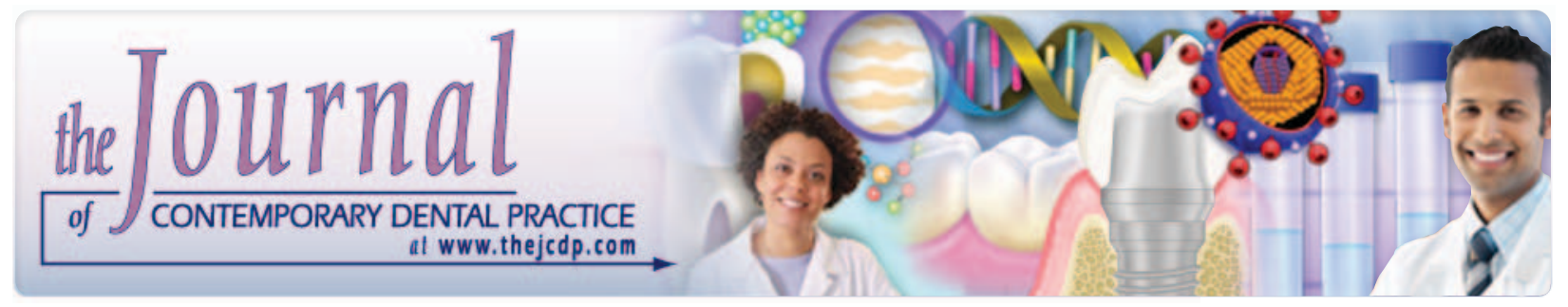

\title{
Incidence of Dry Socket, Alveolar Infection, and Postoperative Pain Following the Extraction of Erupted Teeth
}

Marcelo Carlos Bortoluzzi, DDS, PhD; Rafael Manfro, DDS, PhD; Bruna Eliza De Déa, DDS; Taísa Cristina Dutra, DDS

\begin{abstract}
Aim: The aim of this study was to determine the incidence of dry socket, alveolar infection, and postoperative pain following the routine extraction of erupted teeth.

Methods and Materials: Using a questionnaire, this prospective cross-sectional study evaluated 357 consecutive surgeries in which 473 erupted teeth were extracted by dental students under rigorous control of microbiologic contaminants during a 22-month period. The subject sample consisted of $210(58.8 \%)$ male patients ranging in age from 11 to 79 years (mean $41 \pm 16.3$ ). The most prevalent self-reported ethnicity was Caucasian $(78.2 \%)$. The questionnaire consisted of 60 questions directed to the patient and to the dental student who performed the surgical procedure. The questionnaires were completed before and within seven days after the surgery to obtain outcomes data. Forty-five questionnaires were excluded due to lack of information, inconsistencies, or lack of contact with the patient; however, none had indications of alveolar infection or dry socket. The data were analyzed using descriptive statistics, chi-square tests $\left(x^{2}\right)$, and an odds ratio (OR) as appropriate at the critical level of significance, set at $p<0.05\left(x^{2}\right)$ or $\mathrm{p}<0.01$ ( $\mathrm{x}^{2}$, with the Monte Carlo simulation).
\end{abstract}

Results: The observed incidence was $0.6 \%$ (two cases each) for both alveolar infection and dry socket. Higher pain levels and pain persisting longer than two days were observed

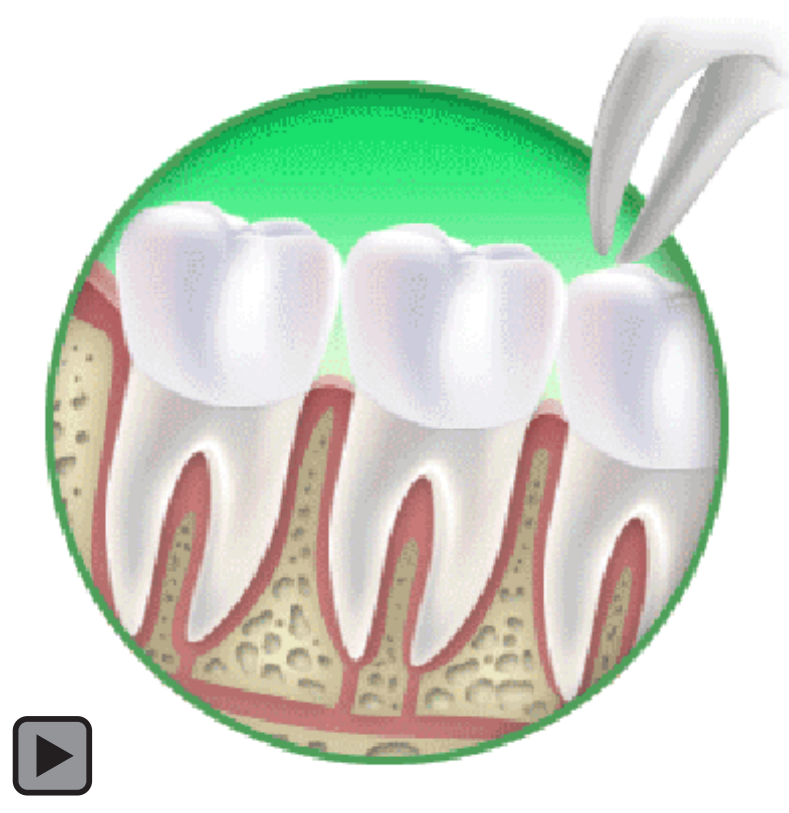

with more traumatic surgeries, or associated with postoperative complications. Smoking was found to be statistically associated with the development of postoperative complications.

Conclusion: The incidence of alveolar infection, dry socket, and severe pain were very low for the routine extraction of erupted teeth. Severe pain that persists for more than two days can represent a sign of a postoperative complication such as dry socket.

Clinical Significance: Dental extraction is part of the dentists' daily work and intercurrences like dry socket, infection, and pain can occur. 
This manuscript reports the incidence of these occurrences and search for its predisposing factors.

Keywords: Dry socket, dental infection, oral surgery, pain

Citation: Bortoluzzi MC, Manfro R, De Déa BE, Dutra TC. Incidence of Dry Socket, Alveolar Infection, and Postoperative Pain Following the Extraction of Erupted Teeth. J Contemp Dent Pract [Internet]. 2010 Jan; 11(1):033-040. Available from: http://www.thejcdp.com/journal/ view/volume11-issue1-bortoluzzi.

\section{Introduction}

Dry socket (DS) is an uncommon condition following the extraction of erupted teeth other than mandibular third molars. DS is the partial or total loss of the post-extraction blood clot, resulting in severe pain that usually starts one to five days postoperatively, with clinical evidence of exposed bone, necrotic debris, and halitosis. ${ }^{1-5}$ Several other terms have been proposed for this condition such as fibrinolytic alveolitis, alveolar osteitis, localized osteomyelitis, postoperative alveolitis, and alveolitis sicca. $\frac{1-6}{}$

While the pathophysiology of DS remains unclear, the most accepted theory is the disintegration of the blood clot in the alveolus by increased fibrinolytic activity. While still a subject of controversy, the theoretical initiation of the fibrinolytic process has been reported to be related to multiple and probably interdependent factors such as the following:

- Age

- Gender

- Use of oral contraceptives

- Smoking

- Duration of surgery

- Condition of the extracted teeth

- Degree of surgical trauma

- Menstrual cycle

- Presence of a preexisting infection or pericoronitis

- Inadequate irrigation or curettage of the socket after extraction

- Low operator experience

- Extraction of mandibular teeth

- Use of excessive amounts of local anesthetic with vasoconstrictor
The reported incidence of DS ranges from 1\% to $45 \%$ and high scores are mainly related to the extraction of impacted third molars. ${ }^{1,8-12}$

Oral surgeries are considered to be cleancontaminated procedures due to the presence of a rich oral microflora. This environment poses a risk for alveolar infection (Al) following single or multiple dental extractions even in healthy subjects, and when they occur repeatedly those are multimicrobial infections. Individuals at risk for a local or general infection also must be considered, such as patients who are immunodepressed, are malnourished, or have an uncontrolled associated systemic disease. The infection rate ranges from $2.7 \%$ to $4.4 \%$ following tooth extractions, with most infections being related to impacted third molar surgery. $\frac{13-16}{}$

While a great deal has been published about third molar extractions, there are scarce data available related to DS and $\mathrm{Al}$ associated with routine erupted dental extraction in the recent literature. ${ }^{14.17}$ Pain that persists for more than two days can be a sign of postoperative complications that can result in clinical resources, operator time that increases costs and stress in a dental practice. Therefore, understanding the development of postoperative pain could be valuable to the clinician in terms of predicting and improving the treatment of these painful episodes.

The aim of this study was to determine the incidence of dry socket, alveolar infection, and postoperative pain following the routine extraction of erupted teeth in realistic clinical conditions using

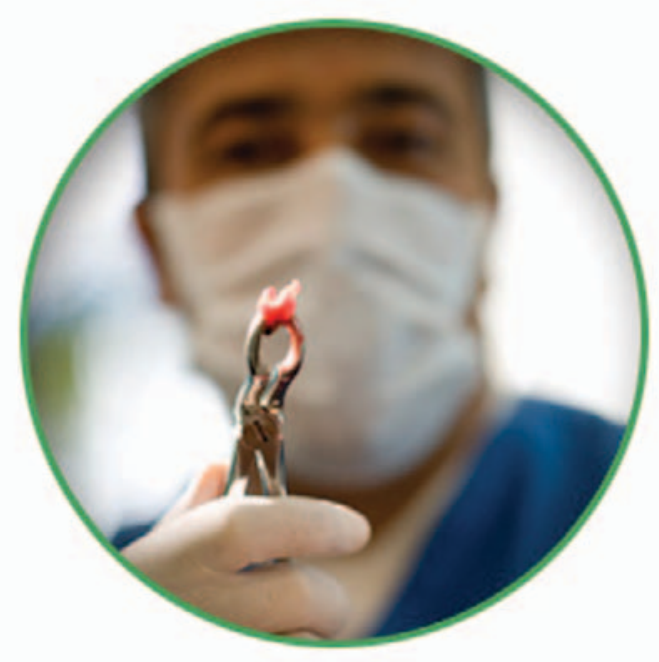


favorable surgical techniques and to search for possible triggering factors for these conditions.

\section{Methods and Materials}

This is a prospective cross-sectional study to determine the incidence of pain, pain persisting longer than two days, dry socket, and alveolar infection following the extraction of erupted teeth. The study was carried out in the oral surgery clinics of the School of Dentistry at the Oeste de Santa Catarina University in Joaçaba, Santa Catarina, Brazil, under the supervision of an oral and maxillofacial surgeon. Using a questionnaire, the study evaluated 357 consecutive surgeries among 210 males (58.8\%) and 147 females $(41.2 \%)$ in an age range from 11 to 79 years (mean $41 \pm 16.3$ ). The most prevalent selfreported ethnicity among the study subjects was Caucasian $(78.2 \%)$. A total of 473 erupted teeth were extracted from these subjects by dental students during a 22-month period between March 2007 and December 2008. The extractions were carried out under similar clinical conditions using rigorous infection control measures.

The questionnaire consisted of 60 questions directed to the patient and to the dental student who performed the surgical procedure. The questionnaires were completed before and within seven days after the surgery to obtain outcomes data. Forty-five questionnaires were excluded due to lack of information, inconsistencies, or inability to contact the patient. However, none had indications of alveolar infection or dry socket.

Outcomes information was obtained by telephone for the patients who were unable return at day seven. All procedures were performed under rigorous infection control measures. All dental handpieces, surgical drills, and instruments were sterilized in an autoclave and a sterile saline solution was used for the lavage of the alveolus and cooling of surgical burs when necessary.

Exclusion criteria included the extraction of third molars that were not fully erupted or classified as difficult for undergraduate dental students to remove and the extraction of deciduous teeth. The criteria for $\mathrm{Al}$ and DS were based on the clinical conditions as previously described by several authors. ${ }^{1,6,13,14,18}$ When present, those conditions were checked and confirmed by at least one of the oral and maxillofacial surgeons of the research team. The clinical criteria for $\mathrm{Al}$ are as follows:

- Suppuration or intraoral abscess in the surgery site.

- Pain persisting or increasing 48 hours after surgery accompanied by intraoral inflammation (moderate or severe) and/or intraoral erythema (moderate or severe) with or without systemic fever.

- Persistent pain for no other justifiable reason that improves with antibiotic treatment.

The clinical criteria for DS are as follows:

- There is severe and persistent pain around the extraction site.

- There is a partially or totally disintegrated blood clot with exposed alveolar bone.

- Halitosis is usually present.

Dry socket is not characterized by redness, swelling, fever, or pus formation, opposing the characteristics of Al. All information concerning the patients' pain levels were self-reported and self-scored.

Analgesics were prescribed for all patients during the postoperative period, but nonsteroidal antiinflammatory drugs (NSAIDs) were prescribed only to those patients when surgical trauma was considered extensive and a more painful postoperative episode was anticipated, as well as for patients who experienced a more painful outcome than expected. Steroidal antiinflammatory drugs were not prescribed for any patient. Antibiotics were used under more specific conditions that included the following:

- Age greater than 65 years

- Immunocompromised patients

- Presence of a low red or white blood cell count

- Existent systemic diseases that implied a potential impairment of the healing process, or body defense capacity

- Surgery performed in areas classified as contaminated and infected

- Presence of an acute inflammatory process

The postoperative care and recommendations were similar for all patients and were directed primarily at keeping the blood clot in place. Postsurgical instruction included avoiding rigorous mouth rinsing, maintaining sensible oral hygiene, and achieving at least 12 hours of rest. 
This study was submitted to the Ethical Committee for Human Research and informed consent was obtained from each patient.

\section{Statistical Analysis}

The data were analyzed using BioEstat, version 4, software (BioEstat, Belém, Pará, Brazil), and descriptive statistics, chi-square tests $\left(x^{2}\right)$, and odds ratio (OR) were used as appropriate at the critical level of significance, set at $p<0.05\left(x^{2}\right)$ or $p<0.01$ ( $x^{2}$, with the Monte Carlo simulation).

\section{Results}

This research evaluated 357 consecutive surgeries with 473 teeth extracted, and 45 questionnaires were excluded due to lack of information, inconsistencies, or lack of contact with the patient; however, none of those had indicated the presence of Al or DS. At least one systemic disease was identified in $19.3 \%$ (69) of the total sample population, including both male and female subjects. Hypertension $(9.2 \%)$ was the most prevalent condition found, followed by diabetes (3.4\%). Among the147 female subjects $(41.2 \%), 37(25.2 \%)$ reported the use of oral contraceptives and six individuals $(4.1 \%)$ reported menstrual bleeding in their monthly cycle on the day of their surgery. Smokers were $20.4 \%$ (73) of the sample; weekly alcohol consumption was declared by $18.8 \%$ (67) of the individuals; and weekly aate (Chimarrão, or ilex paraguariensis) tea consumption was declared by $64.7 \%$ (231) of the individuals.

The mean operating time for surgical procedures was $42( \pm 28.2)$ minutes and single tooth extractions were performed in $74.2 \%$ (265) of the cases. A surgical flap was performed in $38.1 \%$ (136), ostectomy in 16\% (57), and odontotomy in $14.3 \%(51)$ of the cases.

Local anesthetics containing 1:100,000 epinephrine were used for surgical procedures. In 180 cases (50.4\%) $0.036 \mathrm{mg}$ of epinephrine was used (two dental $1.8 \mathrm{ml}$ anesthetic cartridges) and in $4.2 \%(15)$ of the total dental surgeries more than four cartridges $(0.072 \mathrm{mg})$ of adrenalin were used.

Difficult surgeries were reported by $79(22.1 \%)$ students; however, trans-surgical complications occurred in only $7 \%(25)$ of the cases, consisting mainly of root and alveolar fractures, soft tissue lacerations, and oroantral communications.

Acetaminophen was prescribed and used for $346(96.9 \%)$ of the patients; $2(0.6 \%)$ reported that they used another analgesic, while $9(2.5 \%)$ patients reported that did not used any analgesic agent. Antibiotics were prescribed and used for $10.1 \%(36)$ and nonsteroidal anti-inflammatory drugs for $16 \%$ (57) of the patients.

Alveolar infection was detected in two cases $(0.6 \%)$ involving females who were smokers. Daily tobacco consumption was statistically associated with Al ( $p=0.005, x^{2}$ with Monte Carlo simulation-99\%, 10,000 simulations).

DS was observed in two cases $(0.6 \%)$ with one occurring in each sex (Figure 1). No systemic diseases or daily medicine consumption was reported for either case. Tobacco consumption was not statistically significant, although the smoking habit showed a high odds ratio (3.9 OR) for the development of DS with a confidence interval $(\mathrm{Cl})$ of $95 \%$. The same occurred with regard to trans-surgical complications (OR 13.7; $95 \% \mathrm{Cl}$ ). Odontotomy was performed in both cases and was statistically related with DS $\left(p=0.001, x^{2}\right.$ with a Monte Carlo simulation-99\%, 10,000 simulations).

Some variables of interest for $\mathrm{Al}$ and $\mathrm{DS}$ development can be viewed in Table 1.

In order to increase the power of the statistical analyses, DS and Al were considered to be postoperative complications (PC)

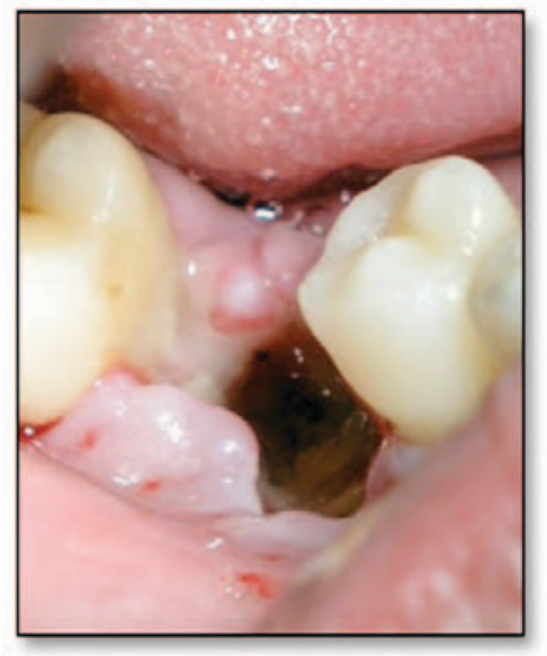

Figure 1. Clinical teatures of a dry socket. 
Table 1. Variables studied and their relation to the development of alveolar infection (Al) and dry socket (DS).

\begin{tabular}{|c|c|c|c|c|c|c|c|c|c|}
\hline \multirow{2}{*}{\multicolumn{2}{|c|}{ Variables }} & \multicolumn{3}{|c|}{ Alveolar Infection (AI) } & \multirow{2}{*}{$\begin{array}{l}\text { Odds } \\
\text { Ratio } \\
\text { (OR) }\end{array}$} & \multicolumn{3}{|c|}{ Dry Socket (DS) } & \multirow{2}{*}{$\begin{array}{l}\text { Odds } \\
\text { Ratio } \\
\text { (OR) }\end{array}$} \\
\hline & & Yes & No & $x^{2}$ & & Yes & No & $x^{2}$ & \\
\hline \multirow{2}{*}{ Gender } & Male & 0 & 210 & & & 1 & 209 & & \\
\hline & Female & 2 & 145 & NS & * & 1 & 146 & NS & 1.4 \\
\hline \multirow{2}{*}{ Age } & \begin{tabular}{|l|} 
Up to 41 \\
years (mean) \\
\end{tabular} & 1 & 190 & & & 2 & 189 & NS & * \\
\hline & \begin{tabular}{|l|} 
More than \\
41 years \\
\end{tabular} & 1 & 165 & NS & 1.15 & 0 & 166 & & \\
\hline \multirow{2}{*}{$\begin{array}{l}\text { Menstrual bleeding days } \\
\text { (when applied) }\end{array}$} & Yes & 0 & 6 & & & 0 & 6 & & \\
\hline & No & 2 & 139 & NS & * & 1 & 140 & NS & * \\
\hline \multirow{2}{*}{$\begin{array}{l}\text { Oral contraceptive (when } \\
\text { applied) }\end{array}$} & Yes & 0 & 37 & & . & 1 & 36 & NS & * \\
\hline & No & 2 & 108 & NS & * & 0 & 110 & & \\
\hline \multirow{2}{*}{ Systemic disease } & Yes & 0 & 69 & & . & 0 & 69 & & \\
\hline & No & 2 & 286 & NS & * & 2 & 286 & NS & * \\
\hline \multirow{2}{*}{ Tobacco consumption } & Yes & 2 & 71 & $p=0.005$ & * & 1 & 72 & NS & 3.9 \\
\hline & No & 0 & 284 & & 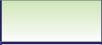 & 1 & 283 & & \\
\hline \multirow{2}{*}{ Alcohol consumption } & Yes & 0 & 67 & & 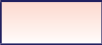 & 0 & 67 & & \\
\hline & No & 2 & 288 & NS & * & 2 & 288 & NS & * \\
\hline \multirow{2}{*}{$\begin{array}{l}\text { Surgical flap (denuding } \\
\text { bone) }\end{array}$} & Yes & 0 & 136 & & . & 1 & 135 & NS & 1.6 \\
\hline & No & 2 & 219 & NS & * & 1 & 220 & & \\
\hline \multirow{2}{*}{ Ostectomy } & Yes & 0 & 57 & & . & 1 & 56 & NS & 5.3 \\
\hline & No & 2 & 298 & NS & ${ }^{*}$ & 1 & 299 & & \\
\hline \multirow{2}{*}{ Odontotomy } & Yes & 0 & 51 & & & 2 & 49 & $p=0.001$ & * \\
\hline & No & 2 & 304 & NS & * & 0 & 306 & & \\
\hline \multirow{2}{*}{ Report of difficult surgery } & Yes & 0 & 79 & & 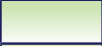 & 1 & 78 & NS & 3.5 \\
\hline & No & 2 & 276 & NS & * & 1 & 277 & & \\
\hline \multirow{2}{*}{$\begin{array}{l}\text { Periodontal disease } \\
\text { present (mouth) }\end{array}$} & Yes & 1 & 91 & NS & 2.9 & 0 & 92 & & \\
\hline & No & 1 & 264 & & & 2 & 263 & NS & * \\
\hline \multirow{2}{*}{ Oral hygiene } & Fair & 1 & 181 & & & 1 & 181 & & \\
\hline & Poor & 1 & 174 & NS & 1.04 & 1 & 174 & NS & 1.04 \\
\hline \multirow{2}{*}{$\begin{array}{l}\text { Small flaws in aseptic } \\
\text { control }\end{array}$} & Yes & 0 & 23 & & & 0 & 23 & & \\
\hline & No & 2 & 332 & NS & * & 2 & 332 & NS & * \\
\hline \multirow{2}{*}{$\begin{array}{l}\text { Postoperative antibiotic } \\
\text { prescription }\end{array}$} & Yes & 0 & 36 & NS & * & 1 & 35 & & \\
\hline & No & 2 & 319 & & & 1 & 320 & NS & \\
\hline \multirow{2}{*}{$\begin{array}{l}\text { Evident purulent discharge } \\
\text { at the surgical site }\end{array}$} & Yes & 0 & 16 & & & 0 & 16 & & \\
\hline & No & 2 & 339 & NS & * & 2 & 339 & NS & * \\
\hline \multirow{2}{*}{$\begin{array}{l}\text { Trans-surgical } \\
\text { complications } \\
\end{array}$} & Yes & 0 & 25 & & & 1 & 24 & NS & 13.7 \\
\hline & No & 2 & 330 & NS & & 1 & 331 & & \\
\hline \multirow{2}{*}{$\begin{array}{l}\text { Adrenalin }(1: 100,000) \\
\text { in anesthetic solution }\end{array}$} & \begin{tabular}{|l} 
Up to \\
$0.036 \mathrm{mg}$
\end{tabular} & 1 & 179 & & & 1 & 179 & & \\
\hline & $\begin{array}{l}\text { More than } \\
0.036 \mathrm{mg} \\
\end{array}$ & 1 & 176 & NS & * & 1 & 176 & NS & * \\
\hline \multirow{2}{*}{ Procedure time (mean) } & \begin{tabular}{|l|} 
Up to 42 \\
minutes
\end{tabular} & 1 & 209 & & & 1 & 209 & & \\
\hline & \begin{tabular}{|l|}
$\begin{array}{l}\text { More than } 42 \\
\text { minutes }\end{array}$ \\
\end{tabular} & 1 & 146 & NS & 1.43 & 1 & 146 & NS & 1.43 \\
\hline
\end{tabular}


statistically associated with daily tobacco consumption ( $p=0.007, x^{2}$ using a Monte Carlo simulation-99\%, 10,000 simulations; OR 12.1; 95\% Cl).

Pain was self-reported in $131(36.7 \%)$ cases with levels described as low by 103 subjects $(28.9 \%)$, moderate by $26(7.3 \%)$, and severe by $2(0.6 \%)$ with DS.

Pain that endured for more than two days was observed in $44(12.3 \%)$ cases and was statistically associated with student reports of difficult surgeries ( $p=0.015, x^{2}$ test; OR 2.2; $95 \% \mathrm{Cl}$ ), and for those surgeries in which more than one tooth was removed $\left(p=0.014, x^{2}\right.$; OR 2.2; $95 \% \mathrm{Cl}$ ). A report of persistent pain of more than two days was associated with female patients who take daily contraceptive drugs ( $p=0.027, x^{2}$; OR $3.0 ; 95 \% \mathrm{Cl}$ ). When pain levels were dichotomized and evaluated as low and moderate/severe, higher pain levels were observed in nonwhite patients $\left(p=0.007, x^{2}\right.$; OR 3.5; $95 \% \mathrm{Cl}$ ), and when an ostectomy was performed $\left(p=0.002, x^{2}\right.$; OR $\left.4.0 ; 95 \% \mathrm{Cl}\right)$ and when an odontotomy was performed ( $p=0.03, x^{2}$; OR $4.0 ; 95 \% \mathrm{Cl}$ ).

\section{Discussion}

It is essential to establish a favorable standard of care to be used by clinicians during the extraction of teeth. The root of such a standard should be based on the principle that any surgical procedure no matter how small has at least some degree of risk of morbidity or mortality. ${ }^{19,20}$ This risk has to be managed appropriately using several strategies.

Risk management begins with a comprehensive evaluation of the physical and medical status of the patient. Routine blood tests (complete blood cell count, blood glucose, and any other tests indicated by an anamnesis) should be performed in order to identify several risk factors for PC in order to avoid them. ${ }^{10,21-23}$ Clinicians need to know and employ biosafety standards and aseptic procedures during any surgical procedure in order to minimize the risk of infection. ${ }^{24}$ Proper planning for the procedure and use of an appropriate operating technique are essential to maximize the potential for a favorable surgical outcome. Favorable postoperative care and patient home

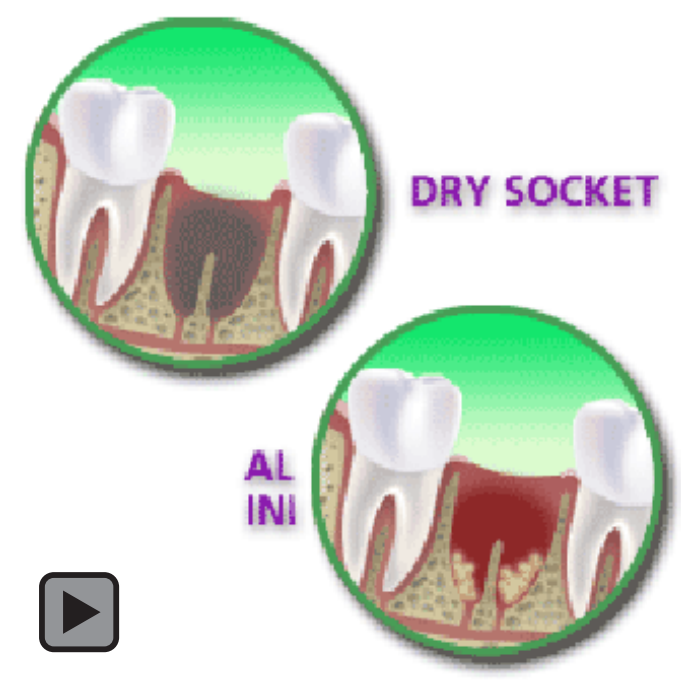

care instructions should be designed to maintain a good oral hygiene and preserve the alveolar blood clot following surgery. The present study utilized these principles with the belief that they represent good practices for extractions, which probably accounted for the incidence of DS and Al remaining below $1 \%$.

In a recent published review article, Noroozi and Philbert ${ }^{10}$ reported that the majority of the literature supports the link between DS and surgical trauma, which was in agreement with the findings of the present study. Using sterile and clean, nonsterile gloves for nonsurgical dental extractions, Adeyemo ${ }^{14}$ found the incidence of healing complications to be dry socket at $8.6 \%$ and one alveolar infection at $9 \%$. That study excluded third molar surgeries but raised some doubt concerning the concept of a "nonsurgical" dental extraction. There is also a question about the lack of information concerning the surgical trauma like that associated with ostectomy and odontotomy because it was unclear if these surgical complements were preformed. Oginni ${ }^{17}$ also reported an incidence of $4.1 \%$ of DS development after 3,319 dental extractions. The reasons for the incidence of DS being so high in Nigeria ${ }^{14,17}$ compared with Brazilian estimates could be related to economics, social and cultural influence on health problems, the principles of surgery utilized, or perhaps all of these factors.

There is some discussion and strong beliefs in the literature that the low experience of the operator could be a trigger for DS. ${ }^{14.17}$ However, in the present study, all procedures were conducted by undergraduate students; thus, low experience 
itself was not related to DS or Al, but rather excessive trauma during the surgical procedure. It can be argued that excessive surgical trauma and low experience are related; $\frac{5,25}{6}$ however, this is not true for all cases. The reason is there are simple and sometimes difficult extractions with varying degrees of damage to adjacent tissues that may have little to do with operator experience.

Due to so few cases of DS and Al it was not possible to perform a more elaborate statistical analysis and interaction between the possible triggering factors for these outcomes in this study. A Monte Carlo simulation for the chi-square test was a mathematic option for the problem; however, it still indicates a probability for a single and isolated factor such as daily tobacco consumption and PC development. Habitual smoking has been found to be a contributing factor for PC, but almost all studies on this subject are related with third molar surgeries..$^{5,10}$ Heng $^{26}$ assessed the contribution of habitual smoking to PC, such as pain, swelling, bleeding, and alveolar osteitis, and found it was related to an increase of these complications following extractions. Al-Belasy ${ }^{2}$ also showed that the incidence of dry socket was higher among cigarette smokers than among nonsmokers (16\% versus $7 \%$ ) for third molar surgeries. Flynn $^{27}$ reported that 15 of $37(41 \%)$ consecutive hospitalized patients with severe odontogenic infections were smokers, indicating that tobacco consumption also may have implications for the development of $\mathrm{Al}$ due to a possible relationship to a patient's state of health.

Pain persisting longer than two days, as well as higher pain levels, were found to be primarily associated with PC development and more surgical trauma (reports of difficult surgery, ostectomy, and odontotomy) in the present study. These results are in accordance with the literature; however, those reports are mainly for third molar surgeries. ${ }^{28,29}$ Benediktsdóttir ${ }^{28}$ implicated the extraction of teeth with curved roots as being more likely to cause high pain levels. This implies the use of ostectomy and odontotomy during these extractions, which is consistent with the findings of the present study. In addition, Baqain ${ }^{29}$ reported that bone removal and tooth sectioning were risk factors for pain.

\section{Conclusion}

This prospective cross-sectional study of the observed incidence for Al and DS following the routine extraction of erupted teeth was $0.6 \%$ for each postoperative complication. Daily tobacco consumption was found to be associated with the development of $\mathrm{Al}$ and an odontotomy and trans-surgical complications were related with development of DS. Pain associated with the development of DS was self-reported in $36.7 \%$ of the cases, however, severe pain occurred only in $0.6 \%$ of the cases. Pain that persisted for more than two days was associated with difficult and more extensive surgeries with female patients who take daily contraceptives.

\section{Clinical Significance}

Dental extractions are a common procedure in a dental practice and may result in complications such as dry socket, alveolar infection, and postoperative pain. This study reveals the incidence of these conditions and examines the predisposing factors associated with the development of these postoperative complications. 


\section{References}

1. Blum IR. Contemporary views on dry socket (alveolar osteitis): a clinical appraisal of standardization, aetiopathogenesis and management: a critical review. Int J Oral Maxillofac Surg. 2002; 31(3):309-17.

2. Al-Belasy FA. The relationship of "shisha" (water pipe) smoking to postextraction dry socket. J Oral Maxillofac Surg. 2004; 62(1):10-4.

3. Torres-Lagares D, Serrera-Figallo MA, Romero-Ruíz MM, Infante-Cossío P, GarcíaCalderón M, Gutiérrez-Pérez JL. Update on dry socket: a review of the literature. Med Oral Patol Oral Cir Bucal. 2005; 10(1):81-5; 77-81.

4. Nusair YM, Goussous ZM. Quantifying the healing of dry socket using a clinical volumetric method. Oral Surg Oral Med Oral Pathol Oral Radiol Endod. 2006; 101(6):e89-95.

5. Oginni FO. Dry socket: a prospective study of prevalent risk factors in a Nigerian population. J Oral Maxillofac Surg. 2008; 66(11):2290-5.

6. Alexander RE. Dental extraction wound management: a case against medicating postextraction sockets. J Oral Maxillofac Surg. 2000; 58(5):538-51.

7. Garcia AG, Grana PM, Sampedro FG, Diago MP, Rey JM. Does oral contraceptive use affect the incidence of complications after extraction of a mandibular third molar? $\mathrm{Br}$ Dent J. 2003; 194(8):453-5.

8. Bergdahl M, Hedström L. Metronidazole for the prevention of dry socket after removal of partially impacted mandibular third molar: a randomised controlled trial. $\mathrm{Br} \mathrm{J}$ Oral Maxillofac Surg. 2004; 42(6):555-8.

9. Caso A, Hung LK, Beirne OR. Prevention of alveolar osteitis with chlorhexidine: a metaanalytic review. Oral Surg Oral Med Oral Pathol Oral Radiol Endod. 2005; 99(2):155-9.

10. Noroozi AR, Philbert RF. Modern concepts in understanding and management of the "dry socket" syndrome: comprehensive review of the literature. Oral Surg Oral Med Oral Pathol Oral Radiol Endod. 2009; 107(1):30-5.

11. Benediktsdóttir IS, Wenzel A, Petersen JK, Hintze H. Mandibular third molar removal: risk indicators for extended operation time, postoperative pain, and complications. Oral Surg Oral Med Oral Pathol Oral Radiol Endod. 2004; 97(4):438-46.

12. Haug RH, Perrott DH, Gonzalez ML, Talwar RM. The American Association of Oral and
Maxillofacial Surgeons Age-Related Third

Molar Study. J Oral Maxillofac Surg. 2005; 63(8):1106-14.

13. Poeschl PW, Eckel D, Poeschl E. Postoperative prophylactic antibiotic treatment in third molar surgery - a necessity? J Oral Maxillofac Surg. 2004; 62(1):3-8.

14. Adeyemo WL, Ogunlewe MO, Ladeinde AL, Bamgbose $\mathrm{BO}$. Are sterile gloves necessary in nonsurgical dental extractions? J Oral Maxillofac Surg. 2005; 63(7):936-40.

15. Lindeboom JA, Frenken JW, Tuk JG, Kroon $\mathrm{FH}$. A randomized prospective controlled trial of antibiotic prophylaxis in intraoral bonegrafting procedures: preoperative single-dose penicillin versus preoperative single-dose clindamycin. Int J Oral Maxillofac Surg. 2006; 35(5):433-6.

16. Brescó-Salinas M, Costa-Riu N, Berini-Aytés L, Gay-Escoda C. Antibiotic susceptibility of the bacteria causing odontogenic infections. Med Oral Patol Oral Cir Bucal. 2006; 11(1):E70-5.

17. Oginni FO, Fatusi OA, Alagbe AO. A clinical evaluation of dry socket in a Nigerian teaching hospital. J Oral Maxillofac Surg. 2003; 61(8):871-6.

18. Arteagoitia I, Diez A, Barbier L, Santamaría G, Santamaría J. Efficacy of amoxicillin/ clavulanic acid in preventing infectious and inflammatory complications following impacted mandibular third molar extraction. Oral Surg Oral Med Oral Pathol Oral Radiol Endod. 2005; 100(1):e11-8.

19. Ricalde P, Engroff SL, Jansisyanont $P$, Ord RA. Paediatric necrotizing fasciitis complicating third molar extraction: report of a case. Int J Oral Maxillofac Surg. 2004; 33(4):411-4.

20. Bergman SA. Perioperative management of the diabetic patient. Oral Surg Oral Med Oral Pathol Oral Radiol Endod. 2007; 103(6):731-7.

21. Gutiérrez JL, Bagán JV, Bascones A, Llamas R, Llena J, Morales A, Noguerol B, Planells P, Prieto J, Salmerón JI. Consensus document on the use of antibiotic prophylaxis in dental surgery and procedures. Med Oral Patol Oral Cir Bucal. 2006; 11(2):E188-205.

22. Hedström L, Sjögren P. Effect estimates and methodological quality of randomized controlled trials about prevention of alveolar osteitis following tooth extraction: a systematic review. Oral Surg Oral Med Oral Pathol Oral Radiol Endod. 2007; 103(1):8-15. 
23. Lacasa JM, Jiménez JA, Ferrás V, Bossom M, Sóla-Morales O, García-Rey C, Aguilar L, Garau J. Prophylaxis versus pre-emptive treatment for infective and inflammatory complications of surgical third molar removal: a randomized, double-blind, placebocontrolled, clinical trial with sustained release amoxicillin/clavulanic acid (1000/62.5 mg). Int J Oral Maxillofac Surg. 2007; 36(4):321-7.

24. Szymanska J. Microbiological risk factors in dentistry. Current status of knowledge. Ann Agric Environ Med. 2005; 12(2):157-63.

25. Adeyemo WL. Etiology of dry socket: additional factors. J Oral Maxillofac Surg. 2004; 62(4):519-20.

26. Heng CK, Badner VM, Clemens DL, Mercer LT, Mercer DW. The relationship of cigarette smoking to postoperative complications from dental extractions among female inmates. Oral Surg Oral Med Oral Pathol Oral Radiol Endod. 2007; 104(6):757-62.

27. Flynn TR, Shanti RM, Levi MH, Adamo AK, Kraut RA, Trieger N. Severe odontogenic infections, part 1: prospective report. J Oral Maxillofac Surg. 2006; 64(7):1093-103.

28. Benediktsdóttir IS, Wenzel A, Petersen JK, Hintze H. Mandibular third molar removal: risk indicators for extended operation time, postoperative pain, and complications. Oral Surg Oral Med Oral Pathol Oral Radiol Endod. 2004; 97(4):438-46.

29. Baqain ZH, Karaky AA, Sawair F, Khaisat A, Duaibis R, Rajab LD. Frequency estimates and risk factors for postoperative morbidity after third molar removal: a prospective cohort study. J Oral Maxillofac Surg. 2008; 66(11):2276-83.

\section{About the Authors}

Marcelo Carlos Bortoluzzi, DDS, PhD

Dr. Bortoluzzi is a professor in the Department of Stomatology and Maxillofacial Surgery of the Santa Terezinha University Hospital and School of Dentistry at Oeste de Santa Catarina University (UNOESC) in Joaçaba, Santa Catarina, Brazil.

e-mail: mbortoluzzi@gmail.com

Rafael Manfro, DDS, PhD

Dr. Manfro is a professor in the Department of Stomatology and Maxillofacial Surgery of the Santa Terezinha University Hospital and School of Dentistry at Oeste de Santa Catarina University (UNOESC) in Joaçaba, Santa Catarina, Brazil.

e-mail: manfrobucomaxilo@ hotmail.com

\section{Bruna Eliza De Déa, DDS}

Dr. De Déa is a general dentist and a research assistant in the School of Dentistry at Oeste de Santa Catarina University (UNOESC) in Joaçaba, Santa Catarina, Brazil.

e-mail: brunetiss@yahoo.com.br

\section{Taísa Cristina Dutra, DDS}

Dr. Dutra is a general dentist and a research assistant in the School of Dentistry at Oeste de Santa Catarina University (UNOESC) in Joaçaba, Santa Catarina, Brazil.

e-mail: taisaodonto@ hotmail.com 